
\title{
25 Research Sourere \\ Effects of various nitrogen regimes on the ability of rapeseed (Brassica napus L.) to suppress littleseed canarygrass (Phalaris minor Retz.)
}

\section{Gaofeng Xu}

Yunnan Academy of Agricultural Sciences https://orcid.org/0000-0003-4110-6306

\section{Shicai Shen}

Yunnan Academy of Agricultural Sciences

\section{Yun Zhang}

Yunnan Academy of Agricultural Sciences

\section{David Roy Clements}

Trinity Western University

Shaosong Yang

Yunnan Academy of Agricultural Sciences

Liyao Dong ( $\nabla$ dly@njau.edu.cn )

Fudou Zhang

Yunnan Academy of Agricultural Sciences

\section{Research article}

Keywords: Rapeseed, Littleseed canarygrass, Nitrogen regimes, Control efficacy, Competitive crops, Photosynthetic characteristics

Posted Date: March 11th, 2021

DOl: https://doi.org/10.21203/rs.3.rs-38850/v2

License: (c) (i) This work is licensed under a Creative Commons Attribution 4.0 International License. Read Full License

Version of Record: A version of this preprint was published at Agronomy on March 16th, 2022. See the published version at https://doi.org/10.3390/agronomy 12030713. 


\section{Abstract}

Background: Littleseed canarygrass (Phalaris minor Retz.) is one of the most troublesome invasive weeds infesting winter crops in Yunnan Province, China. Our previous study found that rapeseed (Bassica napus $\mathrm{L}$.) was a logical candidate crop to control littleseed canarygrass in agroecosystems. Nitrogen $(\mathrm{N})$ could impact plant community composition by altering competitive interactions, however, the effects of different $\mathrm{N}$ regimes on weed control efficacy of rapeseed were unknown. Here, we report the effects of different $\mathrm{N}$ regimes on the competitiveness of rapeseed with littleseed canarygrass and accompanying differences in photosynthetic characteristics.

Results: The results showed that the rapeseed yield and its control efficacy on littleseed canarygrass were significantly affected $(P<0.05)$ under different $N$ regimes, and the control efficacy of littleseed canarygrass by rapeseed increased first and then decreased with the increase of basal nitrogen rates, while increasing topdressing $\mathrm{N}$ rates increased control efficacy of littleseed canarygrass by rapeseed. In fact, yield and weed control efficacy of rapeseed was most ideal when both basal and top-dressing $\mathrm{N}$ was $90 \mathrm{~kg} \cdot \mathrm{ha}^{-1}$. We also found that $\mathrm{N}$ significantly impacted the competitive ability of rapeseed to littleseed canarygrass and rapeseed had the highest competitive ability when both basal and top-dressing $\mathrm{N}$ was $90 \mathrm{~kg} \cdot \mathrm{ha}^{-1}$. With the increase of basal nitrogen rates, competitive balance index (CB) of rapeseed increased initially but decreased beyond an optimal level. CB continually increased with increasing of topdressing $\mathrm{N}$ rates. Our research also showed level and period of $\mathrm{N}$ application had a significant effect $(\mathrm{P}<0.01)$ on the photosynthetic rate $(\mathrm{Pn})$ and chlorophyll content $(\mathrm{Chl})$ of both rapeseed and littleseed canarygrass. Under the same $\mathrm{N}$ application regime, the $\mathrm{Pn}$ and $\mathrm{Chl}$ of littleseed canarygrass were higher than that of rapeseed in December, while the $\mathrm{Pn}$ and $\mathrm{Chl}$ of rapeseed was higher than that of littleseed canarygrass in February. Our study indicated that photosynthetic characteristics of rapeseed and littleseed canarygrass in different growth stages differ in their sensitivity to $\mathrm{N}$ regimes, creating a dynamic competitive relationship.

Conclusions: Together, our results demonstrated that optimal application of fertilizer $\mathrm{N}$ could help rapeseed produce higher yields and greater weed control efficacy, suggesting that future modeling or experimental studies on utilizing crops to control invasive weeds should carefully consider both timing and placement of $\mathrm{N}$.

\section{Background}

Invasive weeds in agro-ecosystems reduce the yield of crops, seriously affecting the export trade of agricultural products, and even threatening ecosystem safety and human health [1,2]. In order to meet these challenges, and to provide alternatives to control by herbicides or mechanical methods environmentally friendly approaches, which have been explored extensively over the past several decades. Ecological control using high value species (e.g., crop species grown locally, native species and/or cash crops) has emerged as a viable option for management of invasive alien plant species [3-5]. Compared with mechanical or chemical control methods, ecological control has generally been 
considered safer, economical, eco-friendly, and sustainable [6]. However, due to increasing demand for food, nitrogen $(\mathrm{N})$ application to croplands has been on the increase [7], which may affect ecological control efficacy. Some studies have shown that increasing $\mathrm{N}$ application rates affect growth and control efficacy of native species on invasive weeds [8-10]. For example, increased $\mathrm{N}$ application was found to increase the invasiveness of the plant, Ambrosia artemisiifolia, as well as its ability to be suppressed by competition with native species [8]. Response to $\mathrm{N}$ levels varies widely by species, which explains although increased $\mathrm{N}$ influences $A$. artemisiifolia favorably, other plants have yet stronger responses to $\mathrm{N}$. Furthermore, increases in biomass due to increased $\mathrm{N}$ can make other nutrients less accessible. Given $\mathrm{N}$ is an indispensable nutrient for agricultural production, studies on the effects of various $\mathrm{N}$ regimes on the ecological control efficacy of native plant for managing invasive weeds are critical for future management of invasive weeds in agroecosystems.

Littleseed canarygrass (Phalaris minor Retz.), an annual weed native to the Mediterranean region [11, 12], is one of the most harmful weeds of winter crops in the world. This weed has spread across Eurasia, South and North America, East and South of Africa and Australia [12,13]. This weed came to China from Mexico via the introduction of wheat in the 1970s and is presently among the most destructive invasive plants in temperate field cropping systems of Yunnan Province, Southwest China [14-16]. Numerous methods have been developed to manage this weed, but the most effective control is generally achieved using herbicides [17-19]. Environmental issues stemming from the use of herbicides, along with the frequent occurrence of herbicide resistance, provide a good rationale for the implementation of alternative control measures [20]. As a promising alternative to traditional control methods, the use of rapeseed to control the invasive weed $P$. minor has recently been reported in China [21].

Rapeseed ranks second among almost all oilseed crops worldwide and is the first-ranked oilseed crop in Yunnan Province [22]. Rapeseed competes strongly with weeds and also exhibits allelopathic activity, facilitating ecological control of weeds in farmland by rapeseed $[16,21]$. For example, one study found that Alopecurus japonicus Steud., Myosolon aquaticum (L.) Mocnch. and Lapsana apogonoides Maxim were significantly inhibited by rapeseed in farmland [23]. Our previous field surveys found that population densities of littleseed canarygrass in rapeseed fields were significantly lower than those in other fields [17]. Subsequent studies examined the effects of rapeseed on littleseed canarygrass growth and reproduction [16]. In mixed culture, rapeseed exhibited greater competitive ability than littleseed canarygrass, and the total biomass, branch, panicles numbers and seed numbers of littleseed canarygrass were suppressed significantly by rapeseed [16, 21]. As one of the key factors affecting crops, weeds and their interactions, $\mathrm{N}$ fertilizer has been widely applied in farmland to increase rapeseed yield. However, the effects of various $\mathrm{N}$ regimes on the efficacy of rapeseed in controlling littleseed canarygrass are not known.

Building on our previous studies $[15,16,17,21]$, the current research examined the influence of various $\mathrm{N}$ application rates on control efficacy of rapeseed and littleseed canarygrass in a field experiment in Yunnan Province, China. Our overall goals were to elucidate mechanisms by which rapeseed competes with littleseed canarygrass under different $\mathrm{N}$ regimes and explore more sustainable management 
methods for littleseed canarygrass in agro-ecosystems. Specifically, our objectives were to: (1) Evaluate impacts of different $\mathrm{N}$ regimes on rapeseed yield and its weed control efficacy; and (2) Measure competitive effects and photosynthetic characteristics of rapeseed and littleseed canarygrass under different $\mathrm{N}$ regimes.

\section{Results}

The impacts of littleseed canarygrass on the growth and yield of rapeseed under various nitrogen regimes

The results showed that the aboveground biomass and yield of rapeseed in all mixed culture treatments were significantly lower $(\mathrm{P}<0.05)$ than that in all monoculture treatments under the same $\mathrm{N}$ application rate (Table 1). Effects of littleseed canarygrass on the growth and yield of rapeseed were significantly different $(P<0.05)$ under various $N$ regimes. In monoculture, the aboveground biomass and yield of rapeseed increased with increasing $N$ application rates. In mixed culture, the biomass and yield of rapeseed were highest for moderate basal $\mathrm{N}$ application rates, but the biomass and yield of rapeseed was highest for the highest topdressing $\mathrm{N}$ application rate. Under different $\mathrm{N}$ regimes, littleseed canarygrass could reduce rapeseed yield by $22.95 \%-54.60 \%$, and yield loss was greatest (over $50 \%$ ) with basal application rates of BN3.

. Table 1. Impacts of littleseed canarygrass on the growth and yield of rapeseed under various nitrogen regimes, including either basal nitrogen $(\mathrm{BN})$ or $(\mathrm{TN})$ topdressing nitrogen treatments.* 


\begin{tabular}{|c|c|c|c|c|c|c|}
\hline \multicolumn{2}{|c|}{ Treatments } & \multicolumn{2}{|c|}{$\begin{array}{l}\text { Total aboveground biomass } \\
\text { of rapeseed ( } \text { g plant }^{-1} \text { ) }\end{array}$} & \multicolumn{2}{|c|}{$\begin{array}{l}\text { Rapeseed yield } \\
\left(\mathrm{Kg} \mathrm{ha}^{-1}\right)\end{array}$} & \multirow[t]{2}{*}{$\begin{array}{l}\text { Yield reduction } \\
\text { rates } \\
\text { of rapeseed (\%) }\end{array}$} \\
\hline BN & TN & Monoculture & $\begin{array}{l}\text { Mixed } \\
\text { culture }\end{array}$ & Monoculture & Mixed culture & \\
\hline \multirow[t]{3}{*}{$\mathrm{BN}_{1}$} & $\mathrm{TN}_{1}$ & $\begin{array}{l}57.1 \pm \\
0.451(\mathrm{a})\end{array}$ & $\begin{array}{l}36.6 \pm \\
0.73 \mathrm{G}(\mathrm{b})\end{array}$ & $\begin{array}{l}1405.3 \pm \\
40.11(a)\end{array}$ & $\begin{array}{l}891.5 \pm \\
29.6 \mathrm{G}(\mathrm{b})\end{array}$ & $36.34 \pm 3.16 \mathrm{~B}$ \\
\hline & $\mathrm{TN}_{2}$ & $\begin{array}{l}65.4 \pm \\
0.91 \mathrm{H}(\mathrm{a})\end{array}$ & $\begin{array}{l}46.4 \pm \\
0.77 \mathrm{~F}(\mathrm{~b})\end{array}$ & $\begin{array}{l}1678.5 \pm \\
23.5 \mathrm{H}(\mathrm{a})\end{array}$ & $\begin{array}{l}1101.5 \pm \\
17.2 F(b)\end{array}$ & $34.35 \pm 1.16 \mathrm{~B}$ \\
\hline & $\mathrm{TN}_{3}$ & $\begin{array}{l}72.7 \pm \\
0.54 \mathrm{G}(\mathrm{a})\end{array}$ & $\begin{array}{l}54.1 \pm \\
0.97 E(b)\end{array}$ & $\begin{array}{l}1843.5 \pm \\
16.4 G(a)\end{array}$ & $\begin{array}{l}1228.8 \pm \\
26.2 \mathrm{E}(\mathrm{b})\end{array}$ & $33.30 \pm 2.04 \mathrm{~B}$ \\
\hline \multirow[t]{3}{*}{$\mathrm{BN}_{2}$} & $\mathrm{TN}_{1}$ & $\begin{array}{l}78.9 \pm \\
1.25 \mathrm{~F}(\mathrm{a})\end{array}$ & $\begin{array}{l}59.6 \pm \\
0.59 \mathrm{D}(\mathrm{b})\end{array}$ & $\begin{array}{l}2256.3 \pm \\
19.9 \mathrm{~F}(\mathrm{a})\end{array}$ & $\begin{array}{l}1651.3 \pm \\
32.5 \mathrm{C}(\mathrm{b})\end{array}$ & $26.79 \pm 1.71 \mathrm{C}$ \\
\hline & $\mathrm{TN}_{2}$ & $\begin{array}{l}87.1 \pm \\
0.46 \mathrm{E}(a)\end{array}$ & $\begin{array}{l}70.7 \pm \\
0.94 \mathrm{~B}(\mathrm{~b})\end{array}$ & $\begin{array}{l}2471.4 \pm \\
18.2 \mathrm{E}(\mathrm{a})\end{array}$ & $\begin{array}{l}1874.8 \pm \\
18.5 B(b)\end{array}$ & $24.15 \pm 0.30 \mathrm{C}$ \\
\hline & $\mathrm{TN}_{3}$ & $\begin{array}{l}92.6 \pm 0.97 \mathrm{D} \\
\text { (a) }\end{array}$ & $\begin{array}{l}76.9 \pm \\
0.81 \mathrm{~A}(\mathrm{~b})\end{array}$ & $\begin{array}{l}2623.3 \pm \\
33.4 \mathrm{D}(\mathrm{a})\end{array}$ & $\begin{array}{l}2021.3 \pm \\
35.5 A(b)\end{array}$ & $22.95 \pm 0.91 \mathrm{C}$ \\
\hline \multirow[t]{3}{*}{$\mathrm{BN}_{3}$} & $\mathrm{TN}_{1}$ & $\begin{array}{l}96.8 \pm \\
0.70 \mathrm{C}(\mathrm{a})\end{array}$ & $\begin{array}{l}52.9 \pm \\
0.78 \mathrm{E}(\mathrm{b})\end{array}$ & $\begin{array}{l}2768.1 \pm \\
21.8 \mathrm{C}(\mathrm{a})\end{array}$ & $\begin{array}{l}1256.2 \pm 23.9 \\
E(b)\end{array}$ & $54.60 \pm 1.22 \mathrm{~A}$ \\
\hline & $\mathrm{TN}_{2}$ & $\begin{array}{l}102.9 \pm \\
1.09 \mathrm{~B}(\mathrm{a})\end{array}$ & $\begin{array}{l}63.4 \pm \\
0.99 \mathrm{C}(\mathrm{b})\end{array}$ & $\begin{array}{l}2864.2 \pm \\
13.7 \mathrm{~B}(\mathrm{a})\end{array}$ & $\begin{array}{l}1318.1 \pm \\
33.8 \mathrm{E}(\mathrm{b})\end{array}$ & $53.97 \pm 1.28 \mathrm{~A}$ \\
\hline & $\mathrm{TN}_{3}$ & $\begin{array}{l}109.7 \pm \\
1.0 \AA(a) 4\end{array}$ & $\begin{array}{l}75.6 \pm \\
1.04 \mathrm{~A}(\mathrm{~b})\end{array}$ & $\begin{array}{l}3024.4 \pm \\
42.7 \mathrm{~A}(\mathrm{a})\end{array}$ & $\begin{array}{l}1434.2 \pm \\
38.8 \mathrm{D}(\mathrm{b})\end{array}$ & $52.57 \pm 1.25 \mathrm{~A}$ \\
\hline \multicolumn{7}{|c|}{$\begin{array}{l}\text { *Data are expressed as means } \pm \text { standard error. Basal nitrogen (BN) rates were } 30,90 \text { and } 150 \mathrm{~kg} \cdot \mathrm{ha}^{-} \\
1 ; \text { Topdressing nitrogen rates (TN) were } 30,60 \text {, and } 90 \mathrm{~kg} \cdot \mathrm{ha}^{-1} \text {. The upper case letters indicate that } \\
\text { the comparison of rapeseed yield or aboveground biomass under different nitrogen application rates } \\
\text { treatments; different upper case letters represent significant differences at } p<0.05 \text {. The lower case } \\
\text { letters in brackets indicate that the comparison of rapeseed yield or aboveground biomass between } \\
\text { monoculture and mixed culture treatments at the same nitrogen condition; different lower case letters } \\
\text { represent significant differences at } p<0.05 \text {. }\end{array}$} \\
\hline
\end{tabular}

\section{The inhibitory effects of rapeseed on littleseed canarygrass under various nitrogen regimes}

The aboveground biomass and seed number of littleseed canarygrass were significantly inhibited $(\mathrm{P}<$ 0.05 ) by rapeseed under various $\mathrm{N}$ regimes (Table 2 ). In monoculture, the aboveground biomass and seed number of littleseed canarygrass increased with increasing $\mathrm{N}$ application rates. In mixed culture, the seed number was significantly decreased by the presence of rapeseed but seed production increased with increasing basal $\mathrm{N}$ application rates. Seed production in mixed culture by littleseed canarygrass decreased with increasing topdressing $\mathrm{N}$ application rates, however. Aboveground biomass of littleseed canarygrass did not differ between $\mathrm{BN}_{1}$ and $\mathrm{BN}_{2}$ treatments, but under the basal $\mathrm{N}$ application rate $\mathrm{BN}_{3}$, 
aboveground biomasses of littleseed canarygrass were significantly higher than for lower basal $\mathrm{N}$ rates (Table 2). Rapeseed exhibited high control efficacy on littleseed canarygrass at low basal $\mathrm{N}$ rates but decreased with increasing basal $\mathrm{N}$ application rates. In mixed culture, seed number of littleseed canary grass was lowest at intermediate basal $\mathrm{N}$ application rates, whereas at highest basal $\mathrm{N}$ application rates control efficacy declined as little seed canary grass was the highest. Furthermore, within the highest basal $\mathrm{N}$ rates, seed production of the weed increased with increasing top dressing rates.

Table 2

Effects of various nitrogen regimes on rapeseed control littleseed canarygrass, including either basal nitrogen (BN) or (TN) topdressing nitrogen treatments.*

\begin{tabular}{|c|c|c|c|c|c|c|}
\hline \multicolumn{2}{|c|}{ Treatments } & \multirow{2}{*}{\multicolumn{2}{|c|}{$\begin{array}{l}\text { Total aboveground biomass } \\
\text { of } \\
\text { littleseed canarygrass ( } \mathrm{g} \\
\text { plant }^{-1} \text { ) }\end{array}$}} & \multirow{2}{*}{\multicolumn{2}{|c|}{$\begin{array}{l}\text { Seed number of littleseed } \\
\text { canarygrass }\end{array}$}} & \multirow[t]{3}{*}{$\begin{array}{l}\text { Control efficacy } \\
(\%)\end{array}$} \\
\hline & & & & & & \\
\hline $\mathrm{BN}$ & $\mathrm{TN}$ & Monoculture & $\begin{array}{l}\text { Mixed } \\
\text { culture }\end{array}$ & Monoculture & Mixed culture & \\
\hline \multirow[t]{3}{*}{$\mathrm{BN}_{1}$} & $\mathrm{TN}_{1}$ & $\begin{array}{l}33.6 \pm \\
0.791(\mathrm{a})\end{array}$ & $\begin{array}{l}17.4 \pm \\
0.71 \mathrm{C}(\mathrm{b})\end{array}$ & $\begin{array}{l}4171.3 \pm \\
35.61(a)\end{array}$ & $\begin{array}{l}2094.3 \pm \\
40.5 \mathrm{D}(\mathrm{b})\end{array}$ & $49.8 \pm 0.73 F$ \\
\hline & $\mathrm{TN}_{2}$ & $\begin{array}{l}36.9 \pm \\
0.60 \mathrm{H}(\mathrm{a})\end{array}$ & $\begin{array}{l}18.5 \pm \\
0.63 \mathrm{C}(\mathrm{b})\end{array}$ & $\begin{array}{l}4491.3 \pm \\
34.4 \mathrm{H}(\mathrm{a})\end{array}$ & $\begin{array}{l}1952.8 \pm \\
41.8 \mathrm{E}(\mathrm{b})\end{array}$ & $56.5 \pm 1.18 \mathrm{E}$ \\
\hline & $\mathrm{TN}_{3}$ & $\begin{array}{l}41.0 \pm \\
0.64 \mathrm{G}(\mathrm{a})\end{array}$ & $\begin{array}{l}19.7 \pm \\
0.75 \mathrm{C}(\mathrm{b})\end{array}$ & $\begin{array}{l}4808.5 \pm \\
66.4 \mathrm{G}(\mathrm{a})\end{array}$ & $\begin{array}{l}1864.5 \pm \\
67.1 \mathrm{E}(\mathrm{b})\end{array}$ & $61.2 \pm 0.88 \mathrm{D}$ \\
\hline \multirow[t]{3}{*}{$\mathrm{BN}_{2}$} & $\mathrm{TN}_{1}$ & $\begin{array}{l}43.7 \pm \\
0.78 \mathrm{~F}(\mathrm{a})\end{array}$ & $\begin{array}{l}17.6 \pm \\
0.88 \mathrm{C}(\mathrm{b})\end{array}$ & $\begin{array}{l}5227.8 \pm \\
74.4 \mathrm{~F}(\mathrm{a})\end{array}$ & $\begin{array}{l}1732.8 \pm \\
27.7 F(b)\end{array}$ & $66.9 \pm 0.63 C$ \\
\hline & $\mathrm{TN}_{2}$ & $\begin{array}{l}47.0 \pm \\
0.61 \mathrm{E}(\mathrm{a})\end{array}$ & $\begin{array}{l}18.8 \pm \\
0.60 \mathrm{C}(\mathrm{b})\end{array}$ & $\begin{array}{l}5557.3 \pm \\
92.5 \mathrm{E}(\mathrm{a})\end{array}$ & $\begin{array}{l}1301.0 \pm \\
29.5 G(b)\end{array}$ & $76.6 \pm 0.56 B$ \\
\hline & $\mathrm{TN}_{3}$ & $\begin{array}{l}49.4 \pm \\
0.76 \mathrm{D}(\mathrm{a})\end{array}$ & $\begin{array}{l}19.3 \pm \\
0.92 \mathrm{C}(\mathrm{b})\end{array}$ & $\begin{array}{l}5989.8 \pm \\
103.4 \mathrm{D}(\mathrm{a})\end{array}$ & $\begin{array}{l}1211.5 \pm \\
33.9 \mathrm{G}(\mathrm{b})\end{array}$ & $79.8 \pm 0.63 \mathrm{~A}$ \\
\hline \multirow[t]{3}{*}{$\mathrm{BN}_{3}$} & $\mathrm{TN}_{1}$ & $\begin{array}{l}53.7 \pm \\
0.53 \mathrm{C}(\mathrm{a})\end{array}$ & $\begin{array}{l}35.3 \pm \\
1.06 \mathrm{~B}(\mathrm{~b})\end{array}$ & $\begin{array}{l}6223.3 \pm \\
82.1 \mathrm{C}(\mathrm{a})\end{array}$ & $\begin{array}{l}3314.8 \pm \\
34.9 \mathrm{C}(\mathrm{b})\end{array}$ & $46.7 \pm 0.73 G$ \\
\hline & $\mathrm{TN}_{2}$ & $\begin{array}{l}59.0 \pm \\
0.72 \mathrm{~B}(\mathrm{a})\end{array}$ & $\begin{array}{l}38.7 \pm \\
0.63 \mathrm{~A}(\mathrm{~b})\end{array}$ & $\begin{array}{l}6558.1 \pm \\
66.1 \mathrm{~B}(\mathrm{a})\end{array}$ & $\begin{array}{l}3623.1 \pm \\
30.18 \mathrm{~B}(\mathrm{~b})\end{array}$ & $45.2 \pm 0.35 G$ \\
\hline & $\mathrm{TN}_{3}$ & $\begin{array}{l}62.3 \pm \\
0.69 \mathrm{~A}(\mathrm{a})\end{array}$ & $\begin{array}{l}40.8 \pm \\
0.86 \mathrm{~A}(\mathrm{~b})\end{array}$ & $\begin{array}{l}6979.5 \pm \\
133.9 \mathrm{~A}(\mathrm{a})\end{array}$ & $\begin{array}{l}3852.5 \pm \\
52.0 A(b)\end{array}$ & $44.8 \pm 1.06 \mathrm{G}$ \\
\hline \multicolumn{7}{|c|}{$\begin{array}{l}\text { *Data are expressed as means } \pm \text { standard error. Basal nitrogen (BN) rates were } 30,90 \text { and } 150 \mathrm{~kg} \cdot \mathrm{ha}^{-} \\
1 \text {; Topdressing nitrogen rates (TN) were } 30,60 \text {, and } 90 \mathrm{~kg} \cdot \mathrm{ha}^{-1} \text {. Control efficacy is based on seed } \\
\text { number. The upper case letters indicate that the comparison of aboveground biomass, seed number } \\
\text { or control efficacy of littleseed canarygrass among different nitrogen fertilization treatments under } \\
\text { the same planting mode(monoculture or mixed culture); different upper case letters represent } \\
\text { significant differences at } p<0.05 \text {. The lower case letters in brackets indicate that the comparison of } \\
\text { aboveground biomass or number of seed between monoculture and mixed culture treatments under } \\
\text { the same nitrogen condition; different lower case letters represent significant differences at } p<0.05 \text {. }\end{array}$} \\
\hline
\end{tabular}




\section{Competitive Interactions of rapeseed and littleseed canarygrass}

The RY of rapeseed and littleseed canarygrass was significantly less $(P<0.05)$ than 1.0 in mixed culture, showing that the intraspecific competition between the two plants was less than their interspecific competition under different nutrient levels (Table 3). The CB (competitive balance) index of rapeseed was significantly greater than zero in mixed culture, except at basal $\mathrm{N}$ level of $\mathrm{BN}_{3}$, which indicates that rapeseed was more competitive than littleseed canarygrass at low and moderate basal $\mathrm{N}$ levels, but sometimes less competitive at high basal $\mathrm{N}$ levels.

Under the same topdressing condition, with increasing basal $\mathrm{N}$ application rates, the RY and CB index of rapeseed first increased and then decreased, and the RY of littleseed canarygrass first decreased and then increased. However, with increasing topdressing $N$ application rate, the RY and CB index of rapeseed increased, the RY of littleseed canarygrass declined.

Table 3

Relative yield (RY) and competitive balance (CB) index of rapeseed and littleseed canarygrass in mixed culture with either basal nitrogen (BN) or (TN) topdressing nitrogen treatments. *

\begin{tabular}{|c|c|c|c|c|}
\hline BN & $\mathrm{TN}$ & Rapeseed RY & Littleseed canarygrass RY & CB index for rapeseed \\
\hline \multirow[t]{3}{*}{$\mathrm{BN}_{1}$} & $\mathrm{TN}_{1}$ & $0.641 \pm 0.016 d^{\star *}$ & $0.517 \pm 0.009 b^{\star \star}$ & $0.216 \pm 0.008 \mathrm{e}^{\star \star}$ \\
\hline & $\mathrm{TN}_{2}$ & $0.709 \pm 0.002 c^{\star \star}$ & $0.501 \pm 0.012 b c^{\star \star}$ & $0.348 \pm 0.015 d^{*} \star \star$ \\
\hline & $\mathrm{TN}_{3}$ & $0.744 \pm 0.008 b^{\star \star}$ & $0.479 \pm 0.014 c^{\star \star}$ & $0.440 \pm 0.019 c^{\star \star}$ \\
\hline \multirow[t]{3}{*}{$\mathrm{BN}_{2}$} & $\mathrm{TN}_{1}$ & $0.756 \pm 0.005 b^{\star \star}$ & $0.401 \pm 0.013 d^{\star \star}$ & $0.635 \pm 0.037 b^{\star \star}$ \\
\hline & $\mathrm{TN}_{2}$ & $0.812 \pm 0.009 a^{\star \star}$ & $0.399 \pm 0.008 d^{\star *}$ & $0.710 \pm 0.009 a^{\star \star}$ \\
\hline & $\mathrm{TN}_{3}$ & $0.831 \pm 0.004 a^{\star \star}$ & $0.391 \pm 0.013 d^{\star \star}$ & $0.755 \pm 0.031 a^{\star \star}$ \\
\hline \multirow[t]{3}{*}{$\mathrm{BN}_{3}$} & $\mathrm{TN}_{1}$ & $0.547 \pm 0.007 e^{\star \star}$ & $0.658 \pm 0.014 a^{\star \star}$ & $-0.186 \pm 0.012 h * *$ \\
\hline & $\mathrm{TN}_{2}$ & $0.616 \pm 0.007 d^{\star \star}$ & $0.655 \pm 0.006 a * \star$ & $-0.061 \pm 0.005 g^{\star \star}$ \\
\hline & $\mathrm{TN}_{3}$ & $0.690 \pm 0.016 c^{\star \star}$ & $0.654 \pm 0.008 a * \star$ & $0.052 \pm 0.016 f \star \star$ \\
\hline \multicolumn{5}{|c|}{$\begin{array}{l}\text { *Data are expressed as means } \pm \text { standard error. Basal nitrogen }(\mathrm{BN}) \text { rates were } 30,90 \text { and } 150 \mathrm{~kg} \cdot \mathrm{ha} \\
1 ; \text { Topdressing nitrogen rates }(\mathrm{TN}) \text { were } 30,60 \text {, and } 90 \mathrm{~kg} \cdot \mathrm{ha}^{-1} \text {. The different letters within same row } \\
\text { mean significant differences at } \mathrm{P}<0.05 \text {. The t-test was used to compare each value with } 1.0 \text { and } 0 \text {; * } \\
\text { and } * * \text { indicate significant differences at } 0.05 \text { and } 0.01 \text { levels, respectively. }\end{array}$} \\
\hline
\end{tabular}

Photosynthetic characteristics 
In December, net photosynthesis rate (Pn) and chlorophyll content (Chl) of littleseed canarygrass were significantly higher than those of rapeseed $(P<0.05)$ in either monoculture or mixed culture (Figs. 1 and 2). With the increasing $\mathrm{N}$ application rates, the $\mathrm{Pn}$ and $\mathrm{Chl}$ of littleseed canarygrass increased; but $\mathrm{Pn}$ and $\mathrm{Chl}$ of rapeseed first increased and then decreased in the mixed culture treatment. Although the $\mathrm{Pn}$ and $\mathrm{Chl}$ of rapeseed or littleseed canarygrass in mixed culture were lower than these parameters in monocluture, there were generally no significant differences for either species. However, for $\mathrm{BN}_{3}$ treatments, the mixed culture rapeseed exhibited significant lower Pn and Chl levels by comparison to the other treatments(Figs. 1 and 2).

In February, the Pn and Chl of rapeseed were significantly higher than that of littleseed canarygrass $(\mathrm{P}<$ 0.05) in both monoculture or mixed culture (except the basal $\mathrm{N}$ application rate of BN3) (Figs. 1 and 2). In monoculture treatments, the $\mathrm{Pn}$ and $\mathrm{Chl}$ for both rapeseed and littleseed canarygrass gradually increased with increasing $\mathrm{N}$ application rates. In mixed culture treatments, $\mathrm{Pn}$ and $\mathrm{Chl}$ of rapeseed were highest at moderate basal $\mathrm{N}$ application rates, whereas $\mathrm{Pn}$ and $\mathrm{Chl}$ of littleseed canarygrass gradually increased as rates increased. However, $\mathrm{Pn}$ and $\mathrm{Chl}$ for both rapeseed and littleseed canarygrass in mixed culture gradually increased with increasing topdressing $\mathrm{N}$ application rates (Figs. 1 and 2).

\section{Discussion}

Utilizing crops to control invasive weeds are regarded as an environmentally friendly approach to the management of invasive weeds in agro-ecosystems $[6,25]$. At the same time, due to the high demand for food, it is important to develop weed control methods to sustain crop yield. $\mathrm{N}$ is essential for plant growth and development and is widely used to improve crop vigor and productivity in agro-ecosystems [26]. Our previous studies found that rapeseed may be used to control littleseed canarygrass in agro-ecosystems [17]. It was generally hypothesized that increasing $N$ rates could improve rapeseed yield and enhance the economic benefits [24]. Furthermore, we theorized that different types of $\mathrm{N}$ application, such as basal or top-dressing applications might influence responses of the crop and the weed as tested here. Crop and weed responses to $\mathrm{N}$ differ and are affected by competition, influencing the outcome of interactions between rapeseed and littleseed canarygrass [16]. We found that increased topdressing $\mathrm{N}$ rates decreased rapeseed yield loss in mixed culture, but the yield losses in rapeseed were even more influenced by basal $\mathrm{N}$ levels. For basal $\mathrm{N}$ application rates of $\mathrm{BN}_{3}\left(150 \mathrm{~kg} \cdot \mathrm{ha}^{-1}\right)$, the yield loss of rape was more than $50 \%$. However, the yield loss of rapeseed was less than $30 \%$ when for basal fertilizer rate $\mathrm{BN}_{2}\left(90 \mathrm{~kg} \cdot \mathrm{ha}^{-1}\right)$. Our results suggested that weed control efficiency of rapeseed was greatly affected by $\mathrm{N}$ application levels, with basal $\mathrm{N}$ levels playing a leading role. Although at higher basal rates rapeseed yield was seriously reduced, intermediate $\mathrm{N}$ application rates may reduce the yield loss of rapeseed and could be successfully manipulated in favor of rapeseed,

Competitiveness of crops plays an important role in determining the likelihood of success in the control of invasive weeds $[4,5,21]$. Although increased $N$ levels can improve the competitiveness and plant growth of both crops and invasives $[8,9]$, the relative effects vary depending on the particular species and 
other conditions, and adaptation for $\mathrm{N}$ uptake and utilization are related to the evolutionary history of invasive species and the artificial selection of crops. .Our evaluation of competitiveness via seed production of littleseed canarygrass provided another view of the effectiveness of various treatments. Just as seen in the biomass measurements, rapeseed showed the highest control efficacy at intermediate basal $\mathrm{N}$ rates, while at the highest $\mathrm{N}$ rates littleseed canarygrass produced substantially higher seed numbers, resulting in a control efficacies in the $40 \%$ range, as compared to $67-80 \%$ at intermediate basal $\mathrm{N}$ rates, depending on accompanying top-dressing rates, with increased topdressing $\mathrm{N}$ rates improving the competitive ability of rapeseed. Thus the $\mathrm{N}$ level and type of fertilization must be regulated carefully to favor rapeseed over littleseed canarygrass.

As an essential nutrient element for plant growth, $\mathrm{N}$ is integral for plant photosynthesis [27]. Higher rates of photosynthesis can lead to increased growth rates, biomass accumulation and overall production [28]. Our current study showed that net photosynthesis rate $(\mathrm{Pn})$ and chlorophyll content (Chl) of littleseed canarygrass were significantly higher than those of rapeseed $(P<0.05)$ in December. At that point in the season, the $\mathrm{Pn}$ and $\mathrm{Chl}$ of littleseed canarygrass increased with increased $\mathrm{N}$ whereas by comparison $\mathrm{Pn}$ and $\mathrm{Chl}$ of rapeseed did not respond as well to the higher fertilizer levels. However, in February, the Pn and $\mathrm{Chl}$ of rapeseed were significantly higher than those of littleseed canarygrass $(P<0.05)$. At this point, increasing basal $\mathrm{N}$ continued to produce higher littleseed canarygrass $\mathrm{Pn}$ rates, but only increased rapeseed rates over the transition from BN1 to BN2; however, topdressed N consistently increased Pn and $\mathrm{Chl}$ in both species. Thus, in the seedling stage, $\mathrm{N}$ demand of littleseed canarygrass was stronger than that of rapeseed, with the result that higher $\mathrm{N}$ levels did not increase rapeseed productivity as much as the invasive plant littleseed canarygrass. However, by the reproductive stage, increasing topdressing $\mathrm{N}$ improved did improve the productivity of rapeseed.

Differences in nutrient requirements of plants at different growth stages is a common phenomenon [29]. If carefully matched to $\mathrm{N}$ demands at various plant growth stages, fertilizer availability could also be manipulated to provide ecological management of invasive alien plants. In our study we found that the net photosynthesis rate $(\mathrm{Pn})$ of rape at seedling stage is weaker than that of littleseed canarygrass, while it is stronger at propagation stage. Our finding of a relatively low net photosynthesis rate $(\mathrm{Pn})$ of rapeseed at the seedling stage, the efficacy of rapeseed in controlling littleseed canarygrass could be improved by timing the fertilizer application appropriately. By using fertilization strategically, e.g., by utilizing topdressing methods, $\mathrm{N}$ could be applied to deliberately to improve the competitive ability of rapeseed over invasive plants like littleseed canarygrass. Control indices are useful to developing clear measures for evaluating invasive plant control efficacy [30]. Our work was the first study to examine rapeseed yield and littleseed canarygrass weed seed number to evaluate the effect of $\mathrm{N}$ regime on their competitive relationship. Our measure of invasive plant control efficacy involved pitting yield of the crop (rapeseed) against the seed production of the weed (littleseed canarygrass), where yield is the measure of crop success and weed seed is essential for the establishment and spread of weed populations. Also key to our approach was showing how the two plants competed at different densities using a De Wit replacement series experiments [25] using biomass to develop an index to evaluate plant interspecific competition [31] as well as yield measures. The data from the De Wit replacement series enabled us to 
calculate competitive balance, which revealed that interspecific competition had a large effect on both species, larger than the effects of intraspecific competition in both cases. It was also clear that topdressing $\mathrm{N}$ application favors rapeseed over littleseed canaraygrass, whereas basal $\mathrm{N}$ applications only favor rapeseed to an intermediate level, but at higher levels the competitive balance is tipped in favor of littleseed canarygrass.

With invasive weeds continuing to threaten food safety and agro-ecosystem sustainability, ecological control using crops or native species may provide safe, economical, and environmentally sustainable solutions for invasive weed management [24,31]. Therefore, choosing crop species with strong competitiveness, high economic value and suitable for large-scale planting have formed the core issues of this study [5]. However, the interspecific competition between plants is dynamic. Environmental factors such as $\mathrm{N}$ availability may affect the interspecific relationship between alternative crops and invasive weeds as demonstrated in our study.

\section{Conclusion}

Our results demonstrated that optimal application of fertilizer $\mathrm{N}$ allowed rapeseed to produce strong yields and provide high efficacy in the control of littleseed canarygrass. We found that interspecific competition and photosynthetic characteristics of rapeseed and littleseed canarygrass could be greatly affected by different nutrient regimes. Littleseed canarygrass growth was more sensitive to basal $\mathrm{N}$ application than topdressing applications. Rapeseed had the strongest competitive ability for intermediate basal and topdressing $\mathrm{N}$ rates of $90 \mathrm{~kg} \cdot \mathrm{ha}^{-1}$. Our study also indicated that photosynthetic characteristics of rapeseed and littleseed canarygrass at different growth stages varied in their sensitivity to varying $\mathrm{N}$ regimes, which showed that optimally planned nutrient regimes may provide a strategic tool for the ecological control of littleseed canarygrass. Finally, we recommend that future modeling or experimental studies on utilizing crops to control invasive weeds in agroecosystems should simultaneously consider impacts of $\mathrm{N}$ application on both crops and weeds to calculate optimum fertilizer rates to maximize crop competitiveness.

\section{Methods}

\section{Study Species}

Littleseed canarygrass (Phalaris minor Retz.) is widely distributed in subtropical and temperate regions in Yunnan Province, Southwest China [14, 17]. Since 2013, littleseed canarygrass seeds have been collected from wheat fields in Songming County of Yunnan Province and propagated in the glasshouse of the Agricultural Environment and Resource Research Institute, Yunnan Academy of Agricultural Sciences, China. The average weight of 1000 seeds was $1.49 \pm 0.05 \mathrm{~g}$ and the germination rate using culture dish filter paper method was $91.8 \%$, as tested before the experimentation. 
Rapeseed (Brassica napus L.) is a dominant oil crop in subtropical and temperate regions of Yunnan Province [22]. Our previous studies showed that rapeseed variety Yunyou No. 2 had strong competitive ability and could be used to control littleseed canarygrass in agroecosystems [24]. In this experiment, the seeds of Yunyou No. 2 were obtained from the Food Research Institute, Yunnan Academy of Agricultural Sciences (YAAS)

\section{Experiment design and data collection}

We conducted a field experiment from September, 2018 to April, 2019 at the Agricultural Environment and Resource Research Institute, Yunnan Academy of Agricultural Sciences, Kunming China $\left(25^{\circ} 12^{\prime}-25^{\circ} 39^{\prime} \mathrm{N}\right.$, $102^{\circ} 76^{\prime}-102^{\circ} 89^{\prime} \mathrm{E}$ ) in the same field as Xu et al. [17]. This area is characterized by a subtropical and temperate monsoon climate. Rainfall averages $1000-1300 \mathrm{~mm}$ per year and the annual mean temperature is $14.1^{\circ} \mathrm{C}$ [17]. The soil type of test site is yellow-brown, with a total $\mathrm{N}$ content of $1.32 \mathrm{~g}^{\mathrm{kg}} \mathrm{g}^{-1}$, Olsen $\mathrm{P}$ content of $29.5 \mathrm{mg} \cdot \mathrm{kg}^{-1}$, and available $\mathrm{K}$ content of $86.4 \mathrm{mg} \cdot \mathrm{kg}^{-1}$, respectively.

The experiment was a split-plot design with basal $\mathrm{N}$ fertilization rates as the whole-plot factor (four replications for each $\mathrm{N}$ application rate treatment), topdressing $\mathrm{N}$ fertilization rates and plant ratios were split-plot factors, utilizing a de Wit replacement series method [32]. The rapeseed and littleseed canarygrass were sown on 24 September 2018 in the greenhouse. On 27 October 2018, similar-sized seedlings of both species(rapeseeds with 6 true leaves and and littleseed canarygrass with 4 leaves) were transplanted into $9 \mathrm{~m}^{2}$ plots $(3 \mathrm{~m} \times 3 \mathrm{~m}$ ) and subjected to different $\mathrm{N}$ fertilization treatments. Three basal $\mathrm{N}$ fertilization rates $\left(30\left(\mathrm{BN}_{1}\right), 90\left(\mathrm{BN}_{2}\right)\right.$ and $\left.150\left(\mathrm{BN}_{3}\right) \mathrm{kg} \cdot \mathrm{ha}{ }^{-1}\right)$ were applied in the form of urea at preplant (26 October 2018), and three topdressing $\mathrm{N}$ fertilization rates $\left(30\left(\mathrm{TN}_{1}\right), 60\left(\mathrm{TN}_{2}\right)\right.$ and $90\left(\mathrm{TN}_{3}\right)$ $\mathrm{kg} \cdot \mathrm{ha}^{-1}$ ) were also applied in the form of urea at bolting stage (26 January 2019). In each plot, the amount of other fertilizers used in the whole growth period was the same, $\mathrm{P}_{2} \mathrm{O}_{5} 90 \mathrm{~kg} \cdot \mathrm{ha}^{-1}, \mathrm{~K}_{2} \mathrm{O} 120$ $\mathrm{kg} \cdot \mathrm{ha}^{-1}$, B $1.6 \mathrm{~kg} \cdot \mathrm{ha}^{-1}$, respectively.

We utilized a de Wit replacement series incorporating three ratios of rapeseed and littleseed canarygrass densities and nine different $\mathrm{N}$ regimes in replicated $9 \mathrm{~m}^{2}$ plots. A combination of three ratios (1:0 (180:0 plants), 1:1 (90:90 plants) and 0:1 (0:180 plants)) of rapeseed and $P$. minor were studied at nine $\mathrm{N}$ fertilization rates $\left(\mathrm{BN}_{1} T N_{1}, \mathrm{BN}_{1} \mathrm{TN}_{2}, \mathrm{BN}_{1} \mathrm{TN}_{3}, \mathrm{BN}_{2} T N_{1}, \mathrm{BN}_{2} \mathrm{TN}_{2}, \mathrm{BN}_{2} \mathrm{TN}_{3}, \mathrm{BN}_{3} \mathrm{TN}_{1}, \mathrm{BN}_{3} T N_{2}, \mathrm{BN}_{3} \mathrm{TN}_{3}\right)$. A total of 180 plants per plot were grown at three ratios of rapeseed and $P$. minor while maintaining a constant planting density of 20 plants $\mathrm{m}^{-2}(0.25 \mathrm{~m} \times 0.20 \mathrm{~m}$ space $)$ in each plot. All plants were distributed uniformly within the plot. All plots were arranged in a complete randomized block design with four replicates per ratio and per nutrient level (total $n=4$ replicates $\times 3$ ratios $\times 9$ nutrient levels $=108$ ). A $1.0 \mathrm{~m}$ border was constructed between plots and each plot was fenced with $0.5 \mathrm{~m}$ high glass panels to avoid being disturbed by herbivores The net photosynthetic rate $(\mathrm{Pn})$ measurements on leaves for rapeseed and littleseed canarygrass conducted using a Portable Photosynthesis System (LI-COR Biosciences LI-6400XT, Lincoln, Nebraska, USA), between 10:00 am and 16:30 pm, with a 6400-02 LED source and $1000 \mu \mathrm{mol} \mathrm{m} \mathrm{m}^{-2} \mathrm{~s}^{-1}$ photosynthetically active radiation [33]. During sampling, $\mathrm{CO}_{2}$ 
concentration in surrounding air, air temperature and relative humidity $(\mathrm{RH})$ in the chamber were measured. In December 2018, two months after transplanting, 40 fully expanded leaves (flag leaf and the top second leaf) of each species were randomly sampled from each plot and immediately scanned using an LI-6400XT [34]. Then, the leaves were cleaned for chlorophyll content determination. We cut $0.1 \mathrm{~g}$ pieces from fresh leaves avoiding the main vein, and soaked the leaf fragments in $25 \mathrm{ml} 95 \%$ ethanol at room temperature for $48 \mathrm{~h}$. The detector was set at $665 \mathrm{~nm}$ in order to calculate the total chlorophyll content (Chl) [28]. In February 2019, four months after transplanting, twenty plants of each species were selected randomly and forty fully expanded sun leaves (flag leaf and the top second leaf) of each species were sampled for net photosynthetic rate and chlorophyll content, following the same method as above. Plants were manually uprooted and then cut at ground level for determination of aboveground biomass. Fresh plants were heated for $30 \mathrm{~min}$ at $105^{\circ} \mathrm{C}$ to halt metabolic processes, and then dried at $80^{\circ} \mathrm{C}$ in a forced-draft oven until reaching a constant weight before weighing. Rapeseed yield and littleseed canarygrass seed number were determined in a $2 \mathrm{~m}^{2}$ area in each plot; rapeseed yield was adjusted to a moisture content of $10.0 \%$.

\section{Data analyses}

To evaluate the effect of littleseed canarygrass on rapeseed yield under various $\mathrm{N}$ regimes, the yield losses of rapeseed were determined from rapeseed yield comparing monoculture versus mixed culture according to the formula: the yield reduction rate of rapeseed $(\%)=(1$ yield in mixed culture $/$ yield in monoculture) $\times 100 \%$. To evaluate the ability of rapeseed to compete effectively with littleseed canarygrass under various $\mathrm{N}$ regimes, we determined the efficacy of littleseed canarygrass suppression by comparing its seed numbers in monoculture versus mixed culture according to the formula: control efficacy of littleseed canarygrass $(\%)=(1$ seed number in mixed culture / seed number in monoculture) $\times 100 \%$.

Relative yield (RY) per plant [35] and competitive balance index (CB) [36] were calculated from the final aboveground biomass obtained for each species in each plot. Relative yield per plant of species $a$ or $b$ in a mixed culture with species $b$ or a was calculated as $R Y_{a}=Y_{a b} / Y_{a}$ or $R Y_{b}=Y_{b a} / Y_{b}$. Competitive balance index was calculated as $\mathrm{CB}_{a}=\ln \left(R Y_{a} / R Y_{b}\right)$, where $Y_{a b}$ is the yield for species a growing with species $b$ ( $g$ /individual), $Y_{b a}$ is the yield for species $b$ growing with species $a, Y_{a}$ is the yield for species a growing in pure culture ( $g$ /individual), and $Y_{b}$ is the yield for species $b$ growing in pure culture. Values of $R Y_{a b}$ measure the average performance of individuals in mixed cultures compared to that of individuals in pure cultures. An $\mathrm{RY}_{\mathrm{ab}}$ of 1.00 indicates species $\mathrm{a}$ and $\mathrm{b}$ are both equal in terms of intraspecific competition and interspecific competition. An $\mathrm{RY}_{\mathrm{ab}}$ greater than 1.00 means intraspecific competition for species a and $b$ is higher than interspecific competition, and an $\mathrm{RY}_{\mathrm{ab}}$ of less than 1.00 implies intraspecific competition of species $a$ and $b$ is less than interspecific competition [37]. Values of $\mathrm{CB}_{a}$ greater than 0 indicate that species $a$ is more competitive than species $b$ [38].

The rapeseed yield and its yield reduction rate, seed number of littleseed canarygrass and its control efficacy, aboveground biomass, physiological (Pn) and chlorophyll content of rapeseed and this weed 
were analyzed by analysis of variance (one-way ANOVA) using IBM SPSS 23.0 software (Armonk, New York, USA). The $\mathrm{F}$ and partial eta squared statistics were calculated considering density ratio and $\mathrm{N}$ level with their interaction as factors at a $5 \%$ level of significance. Relative yield from each mixed culture were compared to the value of 1.00 using t-tests $(a=0.05)$, and values of CB for deviation from 0 using a paired t-test.

\section{Declarations}

\section{Acknowledgments}

We thank those at our study ranches for their hospitality and property access. In particular, we wish to thank Yuhua Zhang from the Agricultural Environment and Resource Research Institute, Yunnan Academy of Agricultural Sciences for her great field support.

\section{Authors' Contributions}

L.Y.D. and F.D.Z. conceived and designed the experiments; G.F.X., S.C.S., S.S.Y., and Y.Z. performed the experiments; G.F.X. and S.C.S. analyzed the data and wrote draft; D.R.C. edited the manuscript for style; L.Y.D. and F.D.Z. commented on manuscript. All authors read and approved the final manuscript.

\section{Funding}

This research was supported by the Applied Basic Research Foundation of Yunnan Province (2017FB055), the Yunnan Provincial Key Fund Program (2018FA024), the Middle-aged and Young Academic Leader Training Foundation of Yunnan Province (2018HB054), the Ten Thousand Talent Program (Young Top-notch Talent) of Yunnan Province (2019-2023), the National Natural Science Foundation of China (31960569), the Special Foundation for Applied Basic Research of Yunnan Academy of Agricultural Sciences (YJM201802), the State Scholarship Fund of China Scholarship Council (201808530029), the Program for the Innovative Research Team of Yunnan Province (20202022), and the Key Research and Development Program of Yunnan Province (2019IB007).

\section{Availability of data and materials}

The datasets used and/or analysed during the present research are accessible from the Corresponding author on reasonable request.

\section{Ethics approval and consent to participate}

All aspects of the study comply with institutional, national, and international guidelines. All experiments were conducted on non-regulated organisms. The study site was rented by Agricultural Environment and Resource Research Institute, Yunnan Academy of Agricultural Sciences and no permits were required to take samples. 
Not applicable.

\section{Competinginterests}

The authors declare no conflict of interest. The founding sponsors had no role in the design of the study; in the collection, analyses, or interpretation of data; in the writing of the manuscript and in the decision to publish the results.

\section{Author details}

${ }^{1}$ College of Plant Protection, Nanjing Agricultural University, Nanjing 210095, China. ${ }^{2}$ Institute of Agricultural Environment and Resources Research, Yunnan Academy of Agricultural Sciences, Kunming 650205, China. ${ }^{3}$ Biotechnology and Germplasm Resources Institute, Yunnan Academy of Agricultural Sciences, Kunming Yunnan, 650205, China. ${ }^{4}$ Biology Department, Trinity Western University, 7600 Glover Road, Langley, V2Y 1 Y1 British Columbia, Canada.

\section{References}

1. Simberloff D,Martin JL, Genovesi P, Maris V, Wardle DA, Aronson J, Courchamp F, Galil B, GarcíaBerthou E, Pascal M, Pyšek P, Sousa R, Tabacchi E, Vilà M. Impacts of biological invasions: what's what and the way forward. Trends Ecol Evol. 2013; 28: 58https://doi.org/10.1016/j.tree.2012.07.013.

2. Blackburn TM, Essl F, Evans T, Hulme PE, Jeschke JM, Kühn I, Kumschick S, Marková Z, Mrugała A, Nentwig W, Pergl J, Pyšek P, Rabitsch W, Ricciardi A, Richardson DM, Sendek A, Vilà M, Wilson JRU, Winter M, Genovesi P, Bacher S. A unified classification of alien species based on the magnitude of their environmental impacts. PLoS Biol. 2014; 12(5): e1001850.https://doi.org/10.1371/journal.pbio.1001850.

3. Sher AA, Marshall DL, Taylor JP. Establishment patterns of native Populus and Salix in the presence of invasive nonnative Tamarix. Eco Appl. 2002; 12: 760-772.https://doi.org/10.1890/10510761(2002)012[0760:EPONPA]2.0.CO;2

4. Li WH,Luo JN,Tian XS,Chow WS, Sun ZY,Zhang TJ,Peng SL,Peng CL. A new strategy for controlling invasive weeds: selecting valuable native plants to defeat them. Sci Rep. 2015; 5: 11004. https://doi.org/10.1038/srep11004.

5. Shen SC, Xu GF, Clements DR, Jin GM, Chen AD, Zhang FD, Hisashi KN. Suppression of the invasive plant mile-a-minute (Mikania micrantha) by local crop sweet potato (Ipomoea batatas) by means of higher growth rate and competition for soil nutrients. BMC Ecol. 2015; 15: 1. https://doi.org/10.1186/s12898-014-0033-5.

6. Richardson DM, Pyšek P. Plant invasions: Merging the concepts of species invasiveness and community invasibility. Prog. Phys. Geogr. 2006; 30: 409-431, doi:10.1191/0309133306pp490pr. 
7. Meng QF, Yue SC, Hou P, Cui Z, Chen, XP. Improving yield and nitrogen use efficiency simultaneously for maize and wheat in China: A Review. Pedosphere. 2016; 26(2):137-147.doi:10.1016/S10020160(15)60030-3.

8. Wang JP, Dong LJ, Sang WG. Effects of different nitrogen regimes on competition between Ambrosia artemisiifolia, an invasive species, and two native species, Artemisia annua and Artemisia mongolica. Biodiversity Science. 2012; 20(1): 3-11. doi: 10.3724/SP.J.1003.2012.09077.

9. Huenneke LF, Hamburg SP, Koide R, Mooney HA, Vitousek PM. Effects of soil resources on plant invasion and community structure in Californian serpentine grassland. Ecol. 1990; 71: 478-491.doi: $10.2307 / 1940302$.

10. Brooks ML. Effects of increased soil nitrogen on the dominance of alien annual plants in the Mojave Desert. J Appl Ecol. 2003; 40: 344-353. http://www.jstor.org/stable/3506007.

11. Gonzalez-Andujar JL, Saavedra M. Spatial distribution of annual grass weed populations in winter cereals. Crop Prot. 2003; 22: 629-633. doi:10.1016/S0261-2194(02)00247-8.

12. Singh S, Kirkwood RC, Marshall G. Biology and control of Phalaris minor Retz. (littleseed canarygrass) in wheat. Crop Prot. 1999; 18: 1-16, doi:10.1016/S0261-2194(98)00090-8.

13. Rajender SC, Ramesh KS. Multiple herbicide resistance in littleseed canarygrass (Phalaris minor): A threat to wheat production in India. Weed Biol Manag. 2008; 8: 112-123.doi:10.1111/j.14456664.2008.00283.x.

14. Shen SC, Zhang FD, Xu GF, Li TL, Wu D, Zhang Y. Occurrence and infestation of invasive weed in crop field in Yunnan. Southwest China J. Agric. Sci. 2012; 25:554-561.

15. Xu GF, Zhang FD, Li TL, Shen SC, Zhang YH. Influence of environmental factors on seed germination of Phalaris paradoxa and Phalaris minor. Acta Bot Boreali-Occident Sin. 2011; 31: 1458-1465. doi: $10.1093 / \mathrm{mp} / \mathrm{ssq} 070$.

16. Xu GF, Zhang Y, Shen SC, Zhang FD, Li TL, Jin GM. Effect of crop species and mixed ratios on morphological plasticity and competitiveness of Phalaris minor Retz. J. Eco-Agric. 2013; 21: 15071514.

17. Xu GF, Zhang FD, Li TL, Shan QL, Zhang YH, Wu D. Biological characteristics, influence on growth of wheat and its economical threshold of Phalaris paradoxa L. and Phalaris minor Retz. Sci Agric Sin. 2010; 43: 4409-4417.

18. Khawar J, Muhammad F, Mubshir H, Hafeezur R, Muhammad AA. Wild oat (Avena fatua L.) and canary grass (Phalaris minor Ritz.) management through allelopathy. J. Plant Prot. Res. 2010;50: 41-44.

19. Tang DS, Yang XY, Li YC, Xiao WX, Gu XJ, Jin DJ, Li R, Fu Y. Investigation on the occurrence, damage and control of the invasive weed Phalaris spp. in Yunnan Province. Plant Prot. 2018; 44: 167-169.

20. Travlos IS, Chachalis D. Glyphosate-resistant hairy fleabane (Conyza bonariensis) is reported in Greece. Weed Technol. 2010; 24: 569-573. doi:10.1614/WT-D-09-00080.1. 
21. Xu GF, Shen SC, Zhang YH, Clements DR, Yang SS, Li J, Dong LY, Zhang FD. Designing cropping systems to improve the management of the invasive weed Phalaris minor Agronomy. 2019: 9,809:112. doi:10.3390/agronomy 9120809.

22. Zhang MH, Liu L, Fu MN. Studies on utilization of Yunnan germplasm resources in rapeseed. Journal of Anhui Agi Sci. 2012; 40(35): 17056-17057.

23. Lou QF, Zhang DY, Huang JZ, Wang QY, Liu TL, Zhu YL. Influence of nitrogen on competition between three weed species and bird rape. Journal of Nanjing Agi Uni. 2000;23(1): 23-26.

24. Liu B, Tao R, Lu JW, Li XK, Cong RH, Wu LS. On-farm trials of site-specific N management for maximum winter oilseed rape (Brassica napus) yield. Journal of Plant Nutrition. 2017, 40(9):13001311. doi:10.1080/01904167.2016.1264599

25. Shen SC, Xu GF, Li DY, Jin GM, Liu SF, Clements DR, Yang YS, Rao J, Chen AD, Zhang FD, Zhu XC. Ipomoea batatas (sweet potato), a promising replacement control crop for the invasive alien plant Ageratina adenophora (Asteraceae) in China. Manag Biol Invasions. 2019; 10: 559-572. https://doi.org/10.3391/mbi.2019.10.3.10

26. Shivega WG, Aldrich-Wolfe L. Native plants fare better against an introduced competitor with native microbes and lower nitrogen availability. AoB Plants. 2017; 9: https://doi.org/10.1093/aobpla/plx004.

27. Jung JK, Lee SU, Kozukue N, Levin CE, Friedman M. Distribution of phenolic compounds and antioxidative activities in parts of sweet potato (Ipomoea batatas) plants and in home processed roots. J Food Compos Anal. 2011; 24: 29-37. https://doi.org/10.1016/j.jfca.2010.03.025.

28. Schjoerring JK, Bock JG, Gammelvind L, Jensen CR, Mogensen VO. Nitrogen incorporation and remobilization in different shoot components of field-grown winter oilseed rape (Brassica napus L.) as affected by rate of nitrogen application and irrigation. Plant Soil. 1995; 177:255-264. doi:10.1007/bf00010132.

29. Lambers $\mathrm{H}$, Poorter $\mathrm{H}$. Inherent variation in growth rate between higher plants: a search for physiological causes and ecological consequences. Adv Ecol Res. 1992; 23: 187-261. https://doi.org/10.1016/S0065-2504(08)60148-8.

30. Wang JP, Dong LJ, Sang WG. Effects of different nitrogen regimes on competition between Ambrosia artemisiifolia, an invasive species, and two native species, Artemisia annua and Artemisia mongolica. Biodiv Sci. 2012; 20: 3-11. http://www.biodiversityscience.net/CN/10.3724/SP.J.1003.2012.09077

31. Weigelt A, Jolliffe P. Indices of plant competition. J Eco. 2003; 91: 707720.https://doi.org/10.1046/j.1365-2745.2003.00805.x

32. de Wit CT. On competition. VersI Landbouwk Onderzoek. 1960; 66: 1-82.http://edepot.wur.nl/187113

33. Field C, Mooney HA. The photosynthesis-nitrogen relationship in wild plants on the economy of plant form and function; Givnish TJ, Ed.; Cambridge University Press: Cambridge, UK, 1986; pp. 2555 . 
34. Pearcy RW, Ehleringer JR, Mooney HA, Rundel PW. Plant Physiological Ecology: Field Methods and Instrumentation; Chapman \& Hall: London, UK, 1989.

35. Fowler N. Competition and coexistence in a North Carolina grassland: III. mixtures of component species. J Ecol. 1982; 70: 77-92. https://www.jstor.org/stable/2259865.

36. Shen SC, Xu GF, Li DY, Jin GM, Liu SF, Clements DR, Yang YS, Rao J, Chen AD, Zhang FD, Zhu XC. Ipomoea batatas (sweet potato), a promising replacement control crop for the invasive alien plant Ageratina adenophora (Asteraceae) in China. Manag Biol Invasions. 2019; 10: 559-572. https://doi.org/10.3391/mbi.2019.10.3.10.

37. Wilson JB. Shoot competition and root competition. J Appl Ecol. 1988; 25: 279-296. https://www.jstor.org/stable/2403626.

38. Fowler N. Competition and coexistence in a North Carolina grassland: III. mixtures of component species. J Ecol. 1982; 70:77-92. https://www.jstor.org/stable/2259865.

\section{Figures}

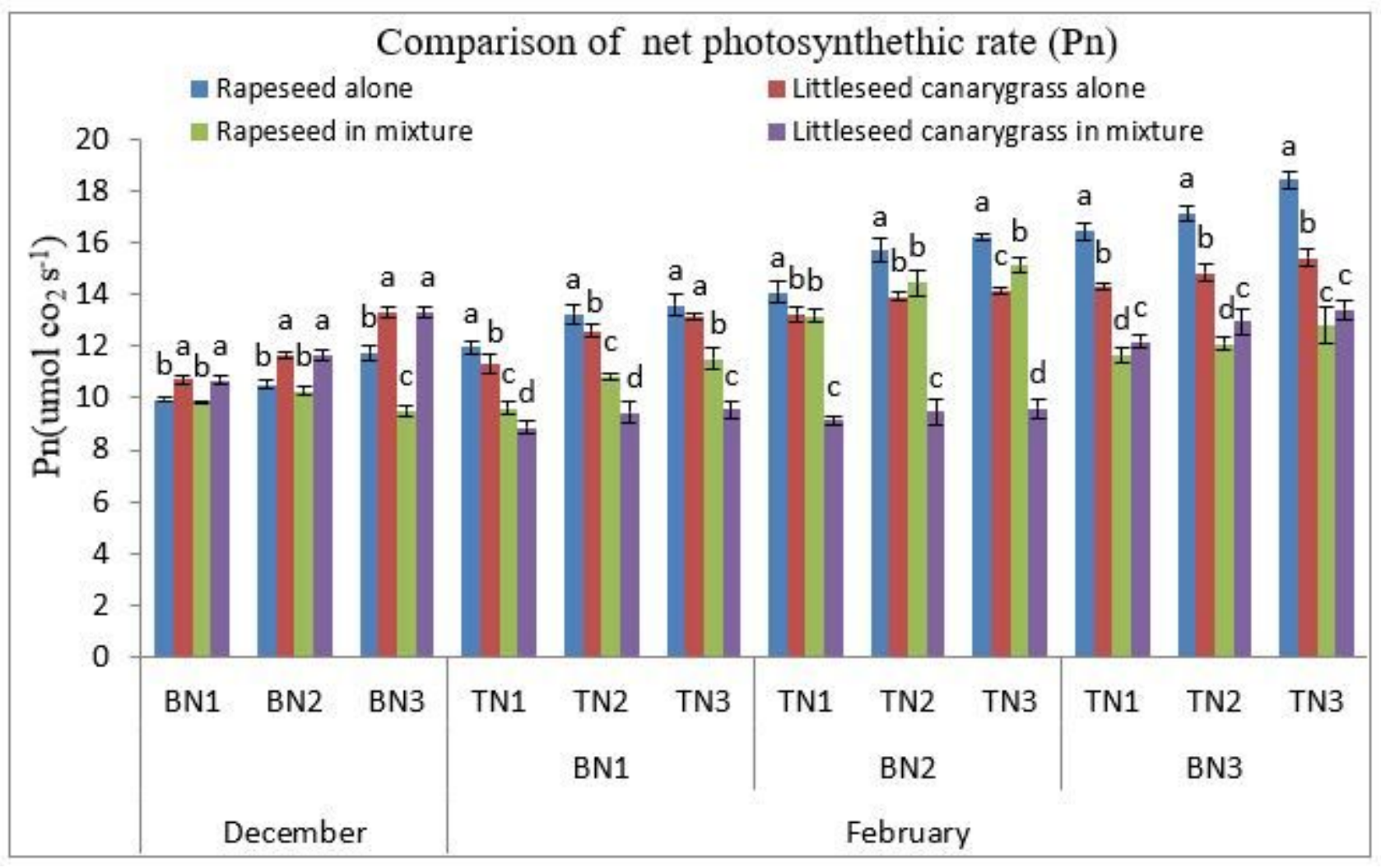

\section{Figure 1}

The effects of different nitrogen regimes on net photosynthetic rate $(\mathrm{Pn})$ of rapeseed and littleseed canarygrass in December and February. Bars are means \pm standard error, different letters represent significant differences under the same nitrogen condition at $p<0.05$, The same below. 


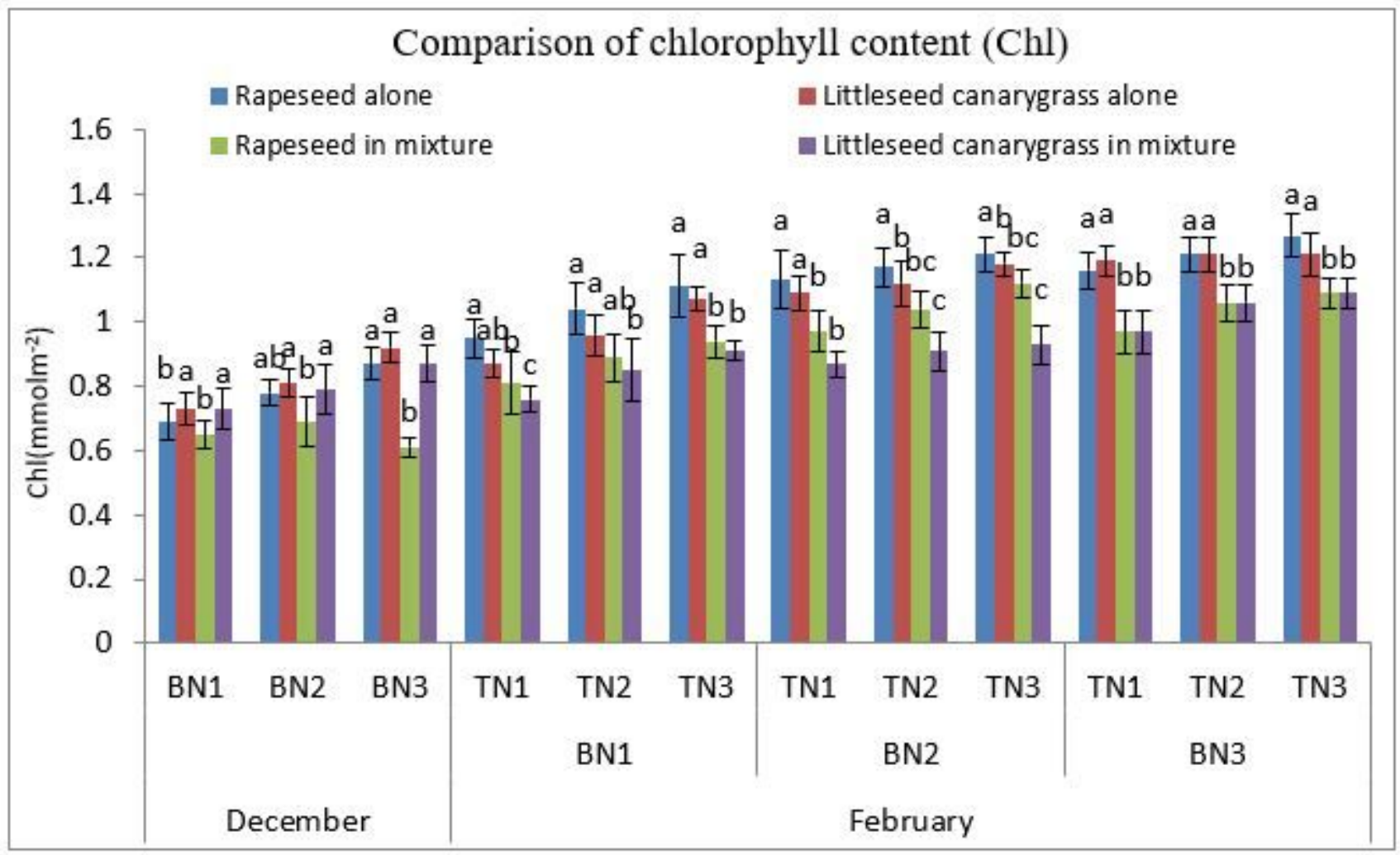

\section{Figure 2}

The effects of different nitrogen regimes on on chlorophyll content of the two species in December and February 